Ryszarda Michalska-Badziak*

\title{
UDZIAt SAMORZĄDU LEKARSKIEGO W WYKONYWANIU ZADAŃ ADMINISTRACJI PUBLICZNEJ
}

Powszechnie przyjmuje się, że samorządy zawodowe uznawane są za formę decentralizacji administracji publicznej. Decentralizacja, na której opiera swoją działalność samorząd, polega na przyznaniu mu wyznaczonej ustawowo samodzielności i niezależności w wykonywaniu konkretnych zadań. Nie jest to jednak całkowite uniezależnienie od państwa, gdyż mogłoby to prowadzić do niepożądanych skutków. Muszą zatem istnieć pewne ograniczenia. W takiej sytuacji nad zdecentralizowanymi podmiotami państwo powinno zagwarantować sobie uprawnienia nadzorcze. Granice samodzielności wyznaczają środki nadzoru przewidziane w odpowiednich ustawach.

Samorząd zawodowy to instytucja publicznoprawna ustanowiona w drodze ustawowej w celu wykonywania części zadań administracji publicznej, polegających na sprawowaniu w interesie publicznym pieczy nad wykonywaniem danego zawodu, mającego charakter zawodu zaufania publicznego i z tego względu poddanego, gdy chodzi o jego wykonywanie, reglamentacji administracyjnej. Sens ustanowienia samorządu polega na tym, że ustawodawca całokształt tych zadań publicznych związanych z reglamentowaniem dostępu do za-

* Ryszarda Michalska-Badziak - doktor nauk prawnych, Katedra Prawa Administracyjnego i Nauki Administracji, Uniwersytet Łódzki. 
wodu i pieczą nad jego należytym wykonywaniem, w tym m.in. kwestie odpowiedzialności zawodowej, postępowania dyscyplinarnego, przekazuje samym zainteresowanym, tzn. korporacji zawodowej, do której przynależy się z mocy prawa.

W doktrynie wskazuje się, że często ratio legis powołania konkretnego samorządu zawodowego stanowi dobro publiczne oraz interes społeczny ${ }^{1}$. Współcześnie w literaturze podnosi się, że do powstania samorządu zawodowego przyczyniają się m.in. konieczność nadawania ustawowych ram działalności określonej grupie zawodowej, w przypadku gdy wykonywanie danego zawodu powinno podlegać szczególnym rygorom z uwagi na interes państwa czy interes społeczny oraz dążenie do stworzenia korporacji zawodowej przez osoby wykonujące dany zawód ${ }^{2}$.

Samorząd w znaczeniu formalnym jest związkiem o charakterze publicznoprawnym posiadającym kompetencje władcze. Z materialnego punktu widzenia jego istotą jest wykonywanie określonych w przepisach prawa powszechnie obowiązującego zadań publicznych wobec swoich członków, a także wobec innych osób. Właśnie realizacja części zadań administracji publicznej ma podstawowe znaczenie dla charakterystyki samorządu zawodowego, w tym również samorządu lekarskiego. Podstawę tego samorządu stanowi zrzeszenie (korporacja) osób, wyodrębniona na podstawie kryterium wykonywania zawodu lekarza (lekarza dentysty). Wykonywanie tego samego zawodu determinuje możliwość stworzenia związku publicznoprawnego, skupiającego dane środowisko zawodowe. Kreowanie tych zrzeszeń następuje w drodze ustawowej. Ich wyodrębnienie dokonywane jest w celu powierzenia im do wykonywania - we własnym imieniu i na własną odpowiedzialność - części zadań i funkcji administracji publicznej.

1 Zob. M. Tabernacka, Zakres wykonywania zadań publicznych przez organy samorząów zawodowych, Wrocław 2007, s. 22; zob. także M. Stahl, Inne podmioty administrujace [w:] System Prawa Administracyjnego, t. 6, Podmioty administrujace, red. R. Hauser, Z. Niewiadomski, A. Wróbel, Warszawa 2011, s. 507.

2 Por. M. Tabernacka, Zakres..., s. 23. 
Normatywną definicję samorządu zawodowego zawiera Konstytucja RP. W art. 17 ust. 1 stanowi ona, że w drodze ustawy można tworzyć samorządy zawodowe, reprezentujące osoby zaufania publicznego i sprawujące pieczę nad należytym wykonywaniem tych zawodów w granicach interesu publicznego i dla jego ochrony. Przepis ten jest jedyną wskazówką odnoszącą się do zaklasyfikowania zawodu lekarza jako zawodu zaufania publicznego. W przepisach prawa brak jest legalnej definicji pojęcia zawodu zaufania publicznego. Próby jego definiowania podjęto w doktrynie. Przykładowo K. Wojtczak uważa, że za zawody zaufania publicznego można uznać te zawody, dla których mogą być tworzone samorządy zawodowe sprawujące pieczę nad należytym wykonywaniem zawodu, w granicach interesu publicznego i dla jego ochrony ${ }^{3}$. Interes publiczny jest rozumiany jako dobro wspólne, którego ochrona wyznacza granice prawem dozwolonej ingerencji administracji publicznej w stosunki społeczno-gospodarcze i w sferę życia prywatnego jednostki. Samorząd zawodowy stoi na straży interesu publicznego poprzez realizację nałożonych na niego zadań publicznych. Dla osób wykonujących dany zawód zaufania publicznego interes publiczny staje się podstawową przesłanką warunkującą sposób wykonywania zawodu i warunki podejmowania czynności zawodowych ${ }^{4}$.

Jednym z zawodów zaufania publicznego jest zawód lekarza. Zawód ten uznawany jest także za wolny zawód. W prawie polskim brak jest legalnej definicji pojęcia wolnego zawodu. Próby jego definiowania podejmowane były w doktrynie przez wielu autorów. K. Wojtczak uznaje, że wolny zawód to osobiste i systematyczne wykonywanie wewnętrznie spójnego zespołu czynności o charakterze intelektualnym, wymagających wysokich kwalifikacji (wiedzy i praktyki), w zamian za honorarium bezinteresownie ustalone, służące zapewnieniu

3 Zob. K. Wojtczak, Reglamentacja zawodów zaufania publicznego ze względu na prawna formę ich wykonywania $w$ świetle rozwiąań polskich i państw członkowskich Wspólnot Europejskich, Warszawa 2002, s. 157; zob. także na ten temat D. Karkowska, Zawody medyczne, Warszawa 2012, s. 265 i n.

${ }^{4}$ Podaję za P. Antkowiak, Samorząd zawodowy w Polsce, Warszawa-Poznań 2012, s. 41. 
świadczeń i usług klientom oraz ochronie istotnych wartości interesu ogólnego, zgodnie z obowiązującymi normami prawnymi, zasadami etycznymi i deontologicznymi ${ }^{5}$.

Samorząd lekarski jest jednym z najstarszych samorządów zawodowych. Powołany został ustawą z 2.12.1921 r. o ustroju i zakresie działania Izb Lekarskich ${ }^{6}$, a następnie podstawą jego organizacji i funkcjonowania była ustawa z 15.03.1934 r. o izbach lekarskich ${ }^{7}$. Po wojnie na krótko wznowił on swoją działalność, gdyż istniał tylko do $1950 \mathrm{r}$. Reaktywowany został w 1989 r. ustawą o izbach lekarskich ${ }^{8}$. Obecnie status prawny samorządu lekarskiego reguluje ustawa o izbach lekarskich z 2009 r. ${ }^{9}$ Według ustawy jednostkami organizacyjnymi samorządu są okręgowe izby lekarskie, Wojskowa Izba Lekarska i Naczelna Izba Lekarska, które działają przez organy określone w ustawie. Każda z izb ma z mocy prawa osobowość prawną.

Zgodnie z treścią art. 2 ust. 1 u.i.l. członkowie izb lekarskich stanowią samorząd zawodowy lekarzy i lekarzy dentystów. Z ust. 2 tego artykułu wynika jednoznacznie, że samorząd zawodowy lekarzy i lekarzy dentystów reprezentuje osoby wykonujące te zawody oraz sprawuje pieczę nad należytym wykonywaniem tych zawodów w granicach interesu publicznego i dla jego ochrony. Interesem publicznym w przypadku zawodu lekarza, zdaniem Trybunału Konstytucyjnego, jest dobro pacjenta w szerokim tego słowa znaczeniu oraz zapewnienie obywatelom usług medycznych wysokiej jakości, a także prawo wyboru przez pacjenta dobrego, godnego zaufania wykonawcy ${ }^{10}$. Niejednokrotnie publiczne zaufanie wymaga od przedstawicieli zawodu lekarza występowania w imieniu pacjenta i chronienia go przed decyzjami innych podmiotów działających w imieniu władzy publicznej,

${ }^{5}$ Por. K. Wojtczak, Zawód i jego prawna reglamentacja. Studium z zakresu materialnego prawa administracyjnego, Poznań 1999, s. 82-84 i 112.

6 Dz.U. Nr 105, poz. 763; zob. szerzej E. Smoktunowicz, Prawo zrzeszania się w Polsce, Warszawa 1992, s. 291; P. Antkowiak, Samorzą..., s. 81 i n.

7 Dz.U. Nr 31, poz. 275 ze zm.

${ }^{8}$ Ustawa z 17.05.1989 r. o izbach lekarskich (Dz.U. Nr 30, poz. 158 ze zm.).

9 Ustawa z 2.12.2009 r. o izbach lekarskich (Dz.U. z 2018 r. poz. 168 ze zm.) - dalej jako: u.i.l.

${ }_{10}$ Wyrok TK z 23.04.2008 r., SK 16/07, OTK-A 2008/3, poz. 45. 
w szczególności w zakresie reglamentowania dostępu do świadczeń opieki zdrowotnej finansowanych ze środków publicznych ${ }^{11}$. Organy tego samorządu mają względem reprezentowanej przez siebie grupy zawodowej charakter przedstawicielski, wykonując bowiem zadania przekazane przez państwo, działają w imieniu tej grupy i pozostają pod jej kontrolą, sprawowaną przez organy powoływane wyłącznie przez członków samorządu. Poprzez prawo wybierania składu swoich organów członkowie korporacji mają wpływ na wykonywanie zadań samorządu. Organy samorządu realizują tę reprezentację także wewnątrz struktury korporacji. Obsadzane w drodze wyborów organy są reprezentantami środowiska zawodowego i wykonują swoją funkcję wobec członków korporacji, jak i podmiotów funkcjonujących poza nią. Na gruncie tej regulacji nie ma wątpliwości, iż kreowana przez te przepisy organizacja zawodowa lekarzy i lekarzy dentystów należy do wspomnianej wcześniej instytucji samorządu zawodowego i ma ona swe bezpośrednie odzwierciedlenie w przepisach Konstytucji RP. Powołana ustawa o izbach lekarskich ani też ustawa o zawodach lekarza i lekarza dentysty ${ }^{12}$ nie przyznają expressis verbis tym zawodom przymiotu zawodu zaufania publicznego. Uczynił to prawodawca w przepisach wykonawczych do ustawy o zawodach lekarza i lekarza dentysty ${ }^{13}$.

Powołanie samorządu lekarskiego wiąże się ze zrzeczeniem się przez państwo części swojej funkcji na rzecz organów tego samorządu, które wykonują za państwo część władztwa publicznego. Na istotę tego samorządu składa się również udzielona mu przez ustawodawcę

11 Por. D. Karkowska, Zawody..., s. 274.

12 Por. ustawa z 5.12.1996 r. o zawodach lekarza i lekarza dentysty (Dz.U. z 2018 r. poz. 617 ze zm.) - dalej jako: u.z.l.

${ }_{13}$ Zob. rozporządzenie Ministra Zdrowia z 26.09.2012 r. w sprawie stażu podyplomowego lekarza i lekarza dentysty (Dz.U. z 2014 r. poz. 474 ze zm.). Powołane rozporządzenie w załączniku nr 1 pkt X - Program stażu z zakresu prawa medycznego. Punkt 5 programu stażu obejmuje zasady działania samorządów reprezentujących zawody zaufania publicznego w ochronie zdrowia, w tym w szczególności: 1) zadania izb lekarskich; 2) prawa i obowiązki członków samorządu lekarskiego; 3) organizację i działanie organów izb lekarskich i zjazdów lekarzy; 4) odpowiedzialność zawodową lekarzy - postępowanie wyjaśniające przed rzecznikiem odpowiedzialności zawodowej, postępowanie przed sądem lekarskim; 5) inne samorządy zawodowe funkcjonujące w ochronie zdrowia - aptekarzy, pielęgniarek i położnych, ich zadania i strukturę. 
samodzielność w zakresie organizacji wykonywania zawodu, określenia warunków jego wykonywania oraz kontroli należytego wykonywania zawodu. Samodzielność samorządu polega na precyzyjnym określeniu przypadków, kiedy państwo może wkraczać w sferę działalności samorządu, a nie jego uniezależnieniu od państwa ${ }^{14}$. Samodzielność przysługuje samorządowi w zakresie spraw wewnątrzkorporacyjnych, jak i zdecentralizowanych na rzecz samorządu spraw publicznych ${ }^{15}$. Ustawodawca nadaje samorządom zawodowym status odrębnych od państwa osób prawnych i w związku z tym ustawowe przekazanie im zadań publicznych jest decentralizacją tych zadań. W granicach interesu publicznego i w dozwolonych granicach samorząd zawodowy otrzymuje prawo kształtowania działalności swoich członków. Oprócz osobowości prawnej istotną cechą samorządu zawodowego, w tym lekarskiego, jest przymusowość członkostwa oraz organizacja wewnętrzna. Obligatoryjne członkostwo powstaje z mocy prawa i stanowi konieczny warunek wykonywania zawodu. Do kwestii obligatoryjnej przynależności do samorządu zawodowego odniósł się Trybunał Konstytucyjny. „Uznał on, że skoro w interesie publicznym i dla ochrony danej korporacji zawodowej samorząd ma sprawować kontrolę nad prawidłowością wykonywania zawodu i czyni to jak gdyby w imieniu władzy publicznej, to nie można zgodzić się z postulatem, aby część osób wykonujących określony zawód była poza strukturami samorządowymi i nie podlegała tej kontroli"16. Organizacja ta musi stwarzać możliwość efektywnego wykonywania zadań oraz zapewnić niezbędną niezależność. Powinna ona opierać się na zasadzie przedstawicielstwa i pozostawać pod kontrolą grupy zawodowej, którą reprezentuje. W ramach pieczy nad wykonywaniem określonego zawodu zróżnicowane są zakresy funkcji administracji publicznej przekazanych im do wykonywania oraz formy i środki

${ }^{14}$ Por. A. Błaś, Administracja samorządu zawodowego [w:] Administracja publiczna, red. J. Boć, Wrocław 2003, s. 64; J. Szreniawski, Prawo administracyjne: część ogólna, Lublin 1994, s. 131; M. Karcz-Kaczmarek, M. Maciejewski, Samorządy zawodowe i zakres ich samodzielności $w$ świetle doktryny i orzecznictwa, „Studia Prawno-Ekonomiczne" 2015/95, s. 59.

15 Zob. M. Tabernacka, Zakres..., s. 25.

${ }_{16}$ Zob. wyrok TK z 22.05.2001 r., K 37/00, OTK 2001/4, poz. 84; zob. także M. Stahl, Inne..., s.511. 
nadzoru ${ }^{17}$. Zakres tej „pieczy” uzależniony jest m.in. od charakteru określonej funkcji publicznej, który powinien wyznaczać granice interesu publicznego i obowiązki w zakresie jego ochrony.

Samorząd lekarski, jak już wcześniej wspomniałam, został ustawowo zobligowany (art. 2 ust. 2 u.i.l.) do sprawowania pieczy nad wykonywaniem zawodu lekarza i lekarza dentysty. Jest to wyraz szczególnej roli, jaką powierzył ustawodawca tej kategorii zawodów. Pojęcie pieczy nie zostało zdefiniowane w przepisach prawa, ale w art. 5 u.i.l. wyznaczony został obszar sprawowania pieczy nad tymi zawodami. Piecza ta dotyczy zapewnienia przez samorząd lekarski kontroli i nadzoru nad prawidłowością wykonywania zawodu - z punktu widzenia prawnego, fachowego i etycznego ${ }^{18}$. W zakresie pieczy sprawowanej nad zawodem lekarza chodzi o zapewnienie ochrony życia i zdrowia pacjentów oraz niedopuszczenie do podważenia zaufania, jakim pacjenci obdarzają osoby wykonujące zawody ingerujące w ich najwyższe wartości. Gwarancją prawidłowego sprawowania pieczy jest przynależność osób wykonujących zawód lekarza do samorządu lekarskiego. Przynależność ta wynika z mocy prawa i jest konsekwencją członkostwa danej grupy zawodowej. Osoba wykonująca zawód lekarza nie może pozostawać poza wspólnotą. Lekarz niebędący członkiem samorządu nie może wykonywać zawodu, jest to prawnie niedopuszczalne. Artykuł 6 u.i.l. nakłada na lekarza zamierzającego wykonywać zawód, któremu okręgowa rada lekarska przyznała prawo wykonywania zawodu, obowiązek wpisu na listę członków tej izby lekarskiej. Pojawia się tu jeszcze jedna kwestia, na którą należy zwrócić uwagę, a mianowicie piecza nad wykonywaniem zawodu lekarza dotyczy wszystkich lekarzy, a nie tylko niektórych. Z analizy art. 2 ust. 3 u.i.l. wynika, że obligatoryjna przynależność lekarzy do samorządu zawodowego pozwala na poddanie pieczy, z drugiej zaś strony ma zapewnić niezależność działania tego samorządu w wykonywaniu swoich zadań i podleganie tylko przepisom prawa, troskę o godność zawodu i ochronę przed różnego rodzaju naciskami ze strony innych podmiotów. Należy podkreślić, iż zgodnie z postano-

\footnotetext{
17 Por. M. Stahl, Inne..., s. 511.

18 D. Karkowska, Zawody..., s. 279.
} 
wieniem Konstytucji RP (art. 191 ust. 1 pkt 4) samorząd zawodowy reprezentujący i sprawujący pieczę nad zawodem zaufania publicznego jest uprawniony do złożenia wniosku do Trybunału Konstytucyjnego w sprawie ustalenia zgodności z Konstytucją RP przepisów dotyczących wykonywania zawodu zaufania publicznego. Organy samorządu lekarskiego w zakresie powierzonym im przez ustawę wykonują zadania $\mathrm{z}$ zakresu administracji publicznej i zastępując w tym zakresie władzę publiczną, muszą one ściśle przestrzegać wyznaczonych im przez przepisy prawa kompetencji. Zgodnie z postanowieniem art. 7 Konstytucji RP mogą one działać na podstawie prawa i w granicach prawa.

Na gruncie ustawy o izbach lekarskich można wyróżnić kilka grup zadań samorządu zawodowego lekarzy. Pierwsza to sprawowanie pieczy nad należytym i sumiennym wykonywaniem zawodu lekarza. Do drugiej grupy należy podejmowanie działań związanych z prawem wykonywania zawodu lekarza i prowadzeniem działalności leczniczej, w tym przyznawanie prawa wykonywania zawodu, zawieszanie, pozbawianie i ograniczanie wykonywania zawodu oraz uznawanie kwalifikacji lekarzy, będących obywatelami państw członkowskich Unii Europejskiej, zamierzających wykonywać zawód lekarza w Polsce. Kolejna grupa to zadania dotyczące utrzymania wysokiego standardu zawodu lekarza, udział w zapewnieniu warunków wykonywania zawodu, realizacji misji społecznej zawodu oraz dbałości o środowisko lekarskie. Do zadań tych należą: ustanawianie zasad etyki lekarskiej obowiązujących wszystkich lekarzy oraz dbałość o ich przestrzeganie, działania na rzecz ochrony zawodu lekarza, w tym występowanie w obronie jego godności oraz interesów indywidualnych i zbiorowych członków samorządu lekarskiego, udzielanie zainteresowanym lekarzom informacji dotyczących ogólnych zasad wykonywania zawodu, zasad etyki lekarskiej, a także o przepisach dotyczących ochrony zdrowia, podejmowanie działań integrujących środowisko lekarskie oraz prowadzenie instytucji samopomocowych i innych form pomocy materialnej dla lekarzy i ich rodzin. Odrębną grupę zadań stanowią zadania związane z odpowiedzialnością zawodową lekarzy. Wśród zadań samorządu lekarskiego wymienić należy także zadania polegające na przepro- 
wadzaniu i organizacji doskonalenia zawodowego lekarzy, opiniowanie w sprawach kształcenia lekarzy, prowadzenie badań dotyczących ochrony zdrowia i wykonywania zawodu lekarza oraz współpracę badawczą z towarzystwami naukowymi, uczelniami, instytutami i jednostkami badawczo-rozwojowymi w kraju i za granicą. Zadania o charakterze opiniotwórczym i reprezentacyjnym obejmują opiniowanie aktów prawnych dotyczących ochrony zdrowia i wykonywania zawodu lekarza bądź występowanie o ich wydanie, opiniowanie warunków pracy i płac lekarzy, zajmowanie stanowiska w sprawach stanu zdrowotności społeczeństwa, polityki zdrowotnej państwa oraz organizacji ochrony zdrowia. W ramach tej grupy zadań wymienić należy także współdziałanie z organami administracji publicznej, związkami zawodowymi i innymi organizacjami w sprawach szeroko rozumianej ochrony zdrowia oraz z samorządami zawodowymi innych zawodów medycznych w kraju i za granicą. Samorząd lekarski powołany jest również do wydawania opinii w sprawach indywidualnych, dotyczących m.in. opiniowania kandydatur lekarzy na stanowiska lub funkcje, jeżeli tak stanowią odrębne przepisy. Ponadto przedstawiciele organów tego samorządu przewodniczą komisjom przeprowadzającym konkursy na stanowisko ordynatora, uczestniczą w konkursach na inne stanowiska w ochronie zdrowia, jeśli przewidują tak odrębne przepisy. Wreszcie ostatnia grupa zadań dotyczy zarządzania izbami lekarskimi, ich działalnością gospodarczą oraz ich majątkiem.

Zaprezentowany katalog zadań samorządu lekarskiego jest otwarty, nie wyczerpują one wszystkich możliwości jego działania. Mogą być temu podmiotowi powierzone inne zadania określone w odrębnych przepisach powszechnie obowiązujących. Natomiast akty wewnętrzne samorządu mogą odnosić się wyłącznie do zakresu administrowania sprawami korporacji.

Do wykonywania powyższych zadań służy samorządowi szereg kompetencji. Nie można się ich zrzec ani przekazać innemu podmiotowi, kompetencje te są chronione prawnie. Przede wszystkim przyznaje on prawo wykonywania zawodu, a także uznaje kwalifikacje lekarzy będących obywatelami państw członkowskich Unii Europejskiej zamie- 
rzających wykonywać zawód na terytorium Polski. Zaznaczyć należy, iż funkcje samorządu w tym zakresie zostały określone poza ustawą o izbach lekarskich. Dokonano tego w powołanej już ustawie o zawodach lekarza i lekarza dentysty. Przyznanie prawa do wykonywania zawodu lekarza następuje w drodze stwierdzenia przez okręgową radę lekarską wystąpienia obligatoryjnych przesłanek określonych w art. 5 u.z.l. Przesłanki te odnoszą się głównie do dokumentów stwierdzających kwalifikacje lekarza. Ocenie podlega również postawa etyczna. Uzyskanie prawa do wykonywania zawodu następuje na podstawie decyzji uprawnionych organów. Okręgowa rada lekarska nie podejmuje czynności zmierzających do stwierdzenia spełnienia określonych ustawą warunków. Organ ten jedynie potwierdza ich spełnienie i podejmuje uchwałę o przyznaniu prawa do wykonywania zawodu. Przyznanie tego prawa ma formę decyzji administracyjnej, mającej charakter deklaratoryjny, co oznacza, że okręgowa rada lekarska potwierdza jedynie spełnienie prawnych przesłanek do wykonywania zawodu. Od tej decyzji przysługuje odwołanie do Naczelnej Rady Lekarskiej. Postępowanie w sprawach przyznawania prawa do wykonywania zawodu lekarza i lekarza dentysty normuje uchwała Naczelnej Rady Lekarskiej z 2010 r. ${ }^{19}$ Przyznanie prawa do wykonywania zawodu oznacza jednocześnie obligatoryjne wpisanie na listę członków okręgowej izby lekarskiej.

Organy samorządu lekarskiego są właściwe w zakresie prowadzenia rejestru określonego w ustawie o działalności leczniczej ${ }^{20}$. Organem prowadzącym rejestr jest okręgowa rada lekarska właściwa dla miejsca wykonywania praktyki zawodowej lekarza. Również organ ten dokonuje zmian wpisu w zakresie danych dotyczących określonego lekarza, w przypadku braku zgłoszenia tych zmian. Właściwa okręgowa rada lekarska może nałożyć karę pieniężną w drodze uchwały. Uchwała ta ma formę decyzji, która posiada rygor natychmiastowej wykonalności. Okręgowa izba lekarska zobligowana jest do przecho-

19 Uchwała NRL 030/10/ V I z 3.09.2010 r. w sprawie szczegółowego trybu postępowania w sprawach przyznawania prawa do wykonywania zawodu lekarza i lekarza dentysty oraz prowadzenia rejestru lekarzy i lekarzy dentystów.

20 Zob. art. 100 ustawy z 15.04.2011 r. o działalności leczniczej (Dz.U. z 2018 r. poz. $160 \mathrm{ze} \mathrm{zm}$.). 
wywania i udostępniania dokumentacji medycznej po zaprzestaniu udzielania świadczeń zdrowotnych w przypadku wskazanym w ustawie o prawach pacjenta ${ }^{21}$.

Okręgowa rada lekarska uprawniona jest do zawieszenia, pozbawienia prawa wykonywania zawodu oraz ograniczenia w wykonywaniu określonych czynności medycznych do czasu zakończenia przeszkolenia w przypadku niedostatecznego przygotowania do zawodu. Organ ten podejmuje w tym zakresie uchwałę.

Samorząd lekarski sprawuje orzecznictwo w przedmiocie niezdolności do wykonywania zawodu lekarza oraz sądownictwo lekarskie w zakresie odpowiedzialności zawodowej lekarzy. Tej odpowiedzialności podlegają lekarze za postępowanie sprzeczne z zasadami etyki i deontologii zawodowej oraz za naruszenie przepisów o wykonywaniu zawodu lekarza. Za przewinienia te sąd lekarski może orzekać przewidziane w przepisach kary.

Osoby wykonujące zawód lekarza zobligowane są do doskonalenia zawodowego, odbywania staży przed-i podyplomowych, a także przeszkolenia w przypadku przerwy w wykonywaniu zawodu. Niedopuszczalne jest arbitralne zamykanie drogi do korzystania $\mathrm{z}$ różnych form doskonalenia zawodowego w oparciu o czynniki inne niż merytoryczne. Organy samorządu lekarskiego są uprawnione do opiniowania i wnioskowania w sprawach kształcenia oraz organizowania doskonalenia zawodowego. W tym celu organy samorządu lekarskiego powinny prowadzić lub brać udział w organizowaniu staży czy szkoleń, a także współdziałać $\mathrm{z}$ innymi podmiotami w tym zakresie. Marszałek województwa ustala z okręgową radą lekarską listę podmiotów uprawnionych do prowadzenia staży podyplomowych. Warto w tym miejscu również wspomnieć o podejmowaniu współpracy między organami administracji rządowej a izbą lekarską ${ }^{22}$.

${ }^{21}$ Zob. art. 30a ust. 3 pkt 3 ustawy z 6.11.2008 r. o prawach pacjenta i Rzeczniku Praw Pacjenta (Dz.U. z 2017 r. poz. 1318 ze zm.).

${ }^{22}$ Zob. umowa z 9.11.2010 r. zawarta pomiędzy Ministrem Obrony Narodowej a Wojskową Radą Lekarską w Warszawie w sprawie współdziałania organów resortu obrony narodowej z Wojskową Izbą Lekarską (Dz.Urz. MON poz. 303). 
Obok zasadniczej roli samorządu, tzn. wykonywania zadań ze sfery administracji publicznej, samorząd ma też na celu reprezentowanie interesów zawodowych korporacji jako takiej, jak i jej członków. Samorząd opiniuje warunki pracy i płac lekarzy, podejmuje działania na rzecz ochrony zawodu lekarza oraz interesów indywidualnych i zbiorowych członków samorządu lekarzy oraz współdziała w sprawach dotyczących warunków wykonywania zawodu lekarza z organami administracji publicznej i związkami zawodowymi. Ustawodawca w obowiązującej ustawie posłużył się pojęciem opiniowania, zaś w poprzedniej zastosowano określenie „negocjowanie”. Oznacza to, że ustawodawca wyraźnie zmierza do wyeliminowania spośród zadań samorządowych tych, które charakterystyczne są dla związku zawodowego.

Samorząd lekarski wykonuje swoje zadania poprzez wykorzystanie różnych prawnych form działania, zarówno o charakterze władczym, jak i niewładczym. Do najistotniejszych władczych form zaliczyć należy wydawanie aktów normatywnych i aktów administracyjnych (decyzje administracyjne). Na podstawie delegacji ustawowej organy samorządu lekarskiego tworzą przepisy zawierające normy prawne kierowane do członków tej korporacji zawodowej, a w pewnych wypadkach obejmują one także swoim zakresem działania osoby spoza korporacji. Należą do nich m.in. akty normatywne zawierające zasady etyki zawodowej ${ }^{23}$, akty określające wewnętrzną strukturę samorządu lekarskiego, programy działania samorządu lekarskiego oraz budżet samorządu lekarskiego. O wykorzystaniu decyzji jako prawnej formy działania samorządu lekarskiego była już mowa wyżej. Organy samorządu lekarskiego podejmują także działania o charakterze niewładczym. Dotyczą one głównie współdziałania z organami administracji publicznej, a także z innymi podmiotami publicznymi i niepublicznymi. Zadania wykonywane przez samorząd lekarski w formach niewładczych są również zadaniami publicznymi. O zaliczeniu ich do tej kategorii zadań decydować będzie to, czy ich realizacja służy interesowi

${ }^{23}$ Obowiązuje Kodeks Etyki Lekarskiej uchwalony przez VII Krajowy Zjazd Lekarzy. 
publicznemu, „dla jego ochrony”24. Zauważyć należy, iż samorząd lekarski, zważywszy na fachowość członków tego samorządu, może w szerokim zakresie inicjować i wykonywać zadania popularyzatorskie w sferze ochrony zdrowia.

Przekazanie pieczy nad wykonywaniem zawodu lekarza korporacji zawodowej związane jest z określeniem na jej rzecz pewnego stopnia samodzielności, a zarazem poddanie działalności tej korporacji nadzorowi państwowemu. Zatem korporacje zawodowe muszą mieć zapewniony odpowiedni stopień samodzielności działania przy realizowaniu powierzonych im ustawowo zadań publicznych ${ }^{25}$. Nadzór, rozumiany jako możliwość władczej ingerencji w funkcjonowanie samorządu, stanowi równocześnie ograniczenie samodzielności, ale również jej gwarancje i zabezpieczenie. W sposób ścisły wyznacza zasady i formy władczej ingerencji państwa, uniemożliwiając podejmowanie wobec samorządu działań nieprzewidzianych w przepisach prawa.

Wykroczenie przez organy samorządu lekarskiego poza zakres dopuszczalnych zadań uruchomi kompetencje nadzorcze ministra właściwego ds. zdrowia (art. 19 ust. 1 i n. u.i.l.). W najszerszym zakresie poddana jest działalność uchwałodawcza samorządu lekarskiego. Minister dysponuje kompetencjami umożliwiającymi inicjowanie konkretnych działań tego samorządu. Może on zwrócić się do poszczególnych organów samorządowych (Krajowego Zjazdu Lekarzy, okręgowego zjazdu lekarzy lub rady lekarskiej) o podjęcie uchwały w sprawach należących do właściwości samorządu, jak też podejmować działania pozwalające weryfikować podjęte rozstrzygnięcia. Służą temu kompetencje do zaskarżania uchwał organów samorządowych do Sądu Najwyższego pod zarzutem ich niezgodności z prawem, w terminie 6 miesięcy od dnia jej otrzymania. Konsekwencją będzie możliwość uchylania podjętych w tym zakresie uchwał organów samorządowych. Jest to środek nadzoru ex post, nastawiony na weryfikację podjętych już rozstrzygnięć.

\footnotetext{
${ }^{24}$ Por. M. Tabernacka, Zakres..., s. 234.

${ }^{25}$ Por. M. Karcz-Kaczmarek, M. Maciejewski, Samorzady..., s. 64.
} 
Reasumując, stwierdzić należy, że samorząd lekarski w sposób samodzielny wykonuje administrację publiczną w zakresie zadań przekazanych im przez ustawę o izbach lekarskich. Szeroki zakres zadań współczesnego państwa wymusza na nim decentralizację. Wykonywanie określonych zadań publicznych przez inne podmioty niż organy administracji przynosi określone korzyści. Samorząd lekarski ustanowiony został w drodze ustawowej w celu realizacji zadań publicznych, polegających na sprawowaniu w interesie publicznym pieczy nad wykonywaniem zawodu lekarza (lekarza dentysty), mającego charakter zawodu zaufania publicznego, poddanego administracyjnoprawnej reglamentacji. Gdyby nie został dla tego zawodu ustanowiony samorząd, wówczas zadania związane z reglamentacją dostępu do zawodu i pieczę nad jego wykonywaniem musiałby sprawować inny podmiot władzy publicznej. Funkcja pieczy obejmuje wszelkiego rodzaju działania związane $\mathrm{z}$ aktywnością zawodową. Podejmowane przez samorząd zadania w tym zakresie realizowane są sprawnie i efektywnie. Posiadane przez samorząd kompetencje pozwalają na władcze decydowanie o dopuszczeniu do zawodu, do ustalania zasad etyki i deontologii zawodowej oraz sprawowania orzecznictwa lekarskiego. Istotną częścią działalności samorządu lekarskiego jest dbanie o standardy moralne i etyczne. Procedura pociągania do odpowiedzialności dyscyplinarnej w zawodzie lekarza była często przedmiotem krytyki publicznej, a także i samego środowiska. Krytyka ta przyczyniła się do przyjęcia nowej regulacji dotyczącej funkcjonowania samorządu zawodowego lekarzy. Należy zgodzić się z poglądami wyrażanymi w doktrynie, że nawet poważne błędy w wykonywaniu zadań publicznych przez samorząd lekarski nie powinny prowadzić do pośpiesznych działań legislacyjnych, ograniczających samodzielność samorządów zawodowych jako publicznych podmiotów administrujących. Pewne zmiany są konieczne ze względu na wzrost liczby członków samorządu lekarskiego i potrzebę jawności ich działania, zwłaszcza w zakresie dopuszczania do wykonywania zawodu oraz sądownictwa dyscyplinarnego. Zmiany wprowadzone w obowiązującej ustawie o izbach lekarskich sprawiły, że zasady postępowania dyscyplinarnego są bardziej przejrzyste i zgodne z ogólnymi normami prawa. Podejmowanie działań reglamentacyjnych zarówno w zakresie dostępu do zawodu, jak i wykonywania czynności zawodowych 
przez członków samorządu lekarskiego musi odbywać się zgodnie z wyrażonymi konstytucyjnie regułami demokratycznego państwa prawnego.

\section{Bibliografia:}

Antkowiak P., Samorzad zawodowy w Polsce, Warszawa-Poznań 2012

Błaś A., Administracja samorządu zawodowego [w:] Administracja publiczna, red. J. Boć, Wrocław 2003

Karcz-Kaczmarek M., Maciejewski M., Samorzady zawodowe i zakres ich samodzielności w świetle doktryny i orzecznictwa, „Studia Prawno-Ekonomiczne” 2015/95

Karkowska D., Zawody medyczne, Warszawa 2012

Smoktunowicz E., Prawo zrzeszania się w Polsce, Warszawa 1992

Stahl M., Inne podmioty administrujace [w:] System Prawa Administracyjnego, t. 6, Podmioty administrujące, red. R. Hauser, Z. Niewiadomski, A. Wróbel, Warszawa 2011

Szreniawski J., Prawo administracyjne: część ogólna, Lublin 1994

Tabernacka M., Zakres wykonywania zadań publicznych przez organy samorzadów zawodowych, Wrocław 2007

Wojtczak K., Reglamentacja zawodów zaufania publicznego ze względu na prawna formę ich wykonywania $w$ świetle rozwiązań polskich i państw członkowskich Wspólnot Europejskich, Warszawa 2002

Wojtczak K., Zawód i jego prawna reglamentacja. Studium z zakresu materialnego prawa administracyjnego, Poznań 1999 